Wafiyuddin Musyaffak And Moses Glorino Rumambo Pandin

Universitas Airlangga

Airlangga St. 4-6, Airlangga, District Gubeng, Surabaya City, East Java 60115

wafiyuddin.musyaffak-2020@ fib.unair.ac.id; moses.glorino@ fib.unair.ac.id

\title{
BOOK REVIEW: "PEMBAHARUAN PEMIKIRAN PENDIDIKAN PAULO FREIRE" (RENEWAL OF EDUCATIONAL THINKING PAULO FREIRE)
}

\author{
Mi'raj Dodi Kurniawan; Malang; 2021; Isbn: 978-623-6709-12-2; Xxvi + 134 Pages
}

The book has the objective of knowing the life history and thoughts of education itself comprehensively. As well as knowing the philosophical ideas, how the opinions of Paulo Freire see that an uncontrolled capitalist process causes unequal education, besides this, it is associated with a system that is being in education in Indonesia. Adding to the intellectual treasures and multiplying the various thoughts on education that exist, which arise from higher education experts and education activists.

Mi'raj's book is essential to read. Of course, it is also studied in depth by various groups, especially by educational thinkers and people in the academic sphere. Discusses in-depth Paulo's thoughts on educational renewal. So that is perfect for the community, including education activists, so that later it can contribute to renewing the structural and cultural dimensions of the nation.

Information or new knowledge from the book is about educational renewal from Paulo Freire's thinking. Education is understood in the form of liberation efforts in thinking and independence in terms of thinking; formal education is not the only solution to thought implications. Not only efforts in liberating thought but also maturing oneself make it well accepted by the wider community and nation. The existence of alternatives or options per the thought input is formal but has breakthroughs, as in Freire's idea. Freire's critical alternative education model can be applied in Indonesia, which can be pursued in structural liberation, welfare, dialogue, and developing essential awareness.

The importance of reviewing Mi'raj's book because it can be used material in the discourse on the development or renewal of thinking from the world of education in Indonesia. With this, it is hope in the future, the revival of educational thought from Freire can dynamize the dialogue of the world of education as a whole and continuously, where the development of this thought does not stop here but will continue to advance per developments. The explanation and elaboration of the contents of the context, it can be outlined that the author provides a problem formulation regarding Paulo Freire's thinking about the renewal of the world of education. But not only from his ideas but also from the background of his time, philosophical thought, contextualization, relevance to Indonesia. With the formulation of the subject matter like that, this book is an intellectual history genre in historiography. So that it is more than sufficient to provide knowledgeable information needed by readers, especially the public in education activists, this book is very suitable and relevant.

Mi'raj Dodi Kurniawan's work provides information that many writers have not studied, especially in Indonesia. Especially in the context of writing from a great person like Paulo Freire. The information presented is Paulo Freire's thinking which is the objective and alternative critical educational method. Indirectly, it means the term education for the oppressed. Apart from that, the aim of the education itself is to empower the community culturally. So later, it will not only present people who can read letters and numbers and present people who are humane and can solve problems.

A book can move a person's thoughts and even actions out of context for good or bad. For readers, it depends on how to react and implement it. The book itself is in the scope of educational philosophy and theory, so it can be used as a source of information and broad knowledge for readers, especially in the field of education. In addition, it can also be reflected and practised in education in Indonesia, which is a developing country like the country of origin of the figure Paulo Freire in Brazil. With such thoughts, the reader can later develop whether it significantly influences him or just in thinking, not in his actions.

The book's presence also certainly leaves an impact both in terms of knowledge or insight for the reader. In Paul Freire's book Renewal of educational thought, it goes into influences such as the birth of alternative views in the life of the nation and state, in which freedom of independent thought needs to be exercised. These alternative thoughts are raised in humanitarian projects such as alleviating poverty and 
reducing ignorance using a good education. Provides a new perspective on education so that readers can judge for themselves the influence of this book with things like this.

One of the interesting studies and evidence is the concept of liberation education in the style of Paulo Freire, wherein his thinking not only prioritizes dialogue and education in solving problems, but education itself must also present people with critical and human awareness by increasing the degree they are in. to himself, to improve the level of his life and also the most important thing is to be able to eliminate any oppression in him. If the number of graduates in this education is overgrowing, it will strengthen the resistance to oppressors and even eliminate or to a minimum. What has happened in Indonesia is an example of persecution that can be seen on pages 113-114 at the bottom. It is written that in 2019 there was a corruption perception index survey involving 180 countries, including Indonesia. Zero score data means that the country is very corrupt, and a score of 100 countries is clean of corruption. Indonesia's index is 40 (including a very corrupt government). From this evidence, it can be said that Indonesia still has no critical awareness and humane education.

From the explanation in the context of this book, it can be said that the study evidence described has been through reliable sources. You can see each quote or reference using the appropriate footnote from the original, and the authenticity of the head can be justified. There are various kinds of sources, including books in Indonesian and foreign languages. There is also evidence in the form of a survey, such as in the case of a corrupt country on page 114 . The survey source has been written from the databooks website. So it can be said that this paper has an actual study. Although there is some subjectivity from the author, it does not remove the main essence of the quote, especially in the thought of the character Paulo Freire.

The first and second sections discuss the history of thought and why Paulo Freire's thought. The first part on page 3 explains that if we think of causality, we see history from the side of the effect and see it as a cause. Where when history is considered. As a result, the past is present because of the reasons that preceded it. Meanwhile, if it is regarded as a cause, it will be seen as the result of the incident. The second part deals specifically with Paulo Freire, which describes his birth, life, and death. This can be seen on page 9. The thought of this figure is exciting because it can be a solution to answer the problems of the times, especially in upholding social and economic justice and a way out of the existence of educational practices. In the third, fourth, fifth, sixth, and seventh sections, we still discuss the thoughts and track records of Paulo Freire with his views on education. Paulo Freire grew up in a middle-income family, but then when he was a child, his family's economy changed drastically, and he could be flawed. This was due to the global economic depression of the United States in 1929, which affected this third world country (Brazil), which can be seen on page 26. From here, Freire started to think about renewing thinking in the world of education. Paulo Freire was better known as an educational philosopher and political activist until the end of his own life. Thinking and getting down directly with his ideas into action, he did this because of his attention to education. Freire's thoughts are not only one but many, but one of the most important and famous is the movement of the oppressed ( pedagogy of the oppressed ). Activists very much love this topic in various parts of the world in their vision of social justice.

The eighth and ninth sections, which are the final sections, discuss the renewal of thought in education and education that liberates Indonesia. According to Freire, educational renewal takes the premise of the concept of culture, knowledge, and the condition of the people who are disadvantaged and oppressed. In the previous educational concept, it only took certain concepts. But Freire alone took the concept of the oppressed's social, political, and economic conditions as a rationale for building a world of a good education. Hence it is in this. It is an educational renewal. See page 108.

The last part is the relevance of this idea to education in Indonesia. Paulo Freire is from Brazil, which has some similarities with Indonesia. These two countries are developing countries, and both are hostile to oppression and fight for freedom for a just and prosperous society, which can be seen on page 112. Freire's model of thought is needed and applied in this country because it has the same vision and mission between the two countries. Because some Indonesian people themselves still experience both cultural and structural oppression, impoverishment, being educated in a bank style and still controlled with magical awareness. You can see the evidence on the next page. Namely, 113, where the law of justice is still not upheld, economic and political oligarchs are still clearly visible, both central and regional, corruption is still rampant. Indonesia has a relatively literate population, but that does not mean that the problem has been resolved because the issues above are still alive in society. Therefore the thoughts of Paulo Freire will foster the literacy movement, promote critical dialectics and education towards humans and humans, which improves the standard of life and upholds social justice in education and community life. 
The book's writing style is clear, with easy-to-digest terms, the structure of the sentences is easy to understand for the reader even though he does not have a philosophical or historical background. Readers will quickly understand the context of the contents. The organization itself is structured in paragraphs and has cohesion (unity) in which the sentences formed by sections are well laid out. And also, between paragraphs are continuous (coherence) so that the reader quickly understands this. The size of the book itself is the standard size of a reading book with a length of $15.5 \mathrm{~cm}$ x $23 \mathrm{~cm}$ with some pages xxvi +134 pages. Books with physical dimensions like this are classic books circulating in Indonesia with easy-to-understand language, not wordy, let alone about education. So that according to readers, especially academics, education activists, and even activists, it is suitable as a reference.

Regarding studies, facts and ideas so far in the book have not been overlooked. Even though it is only 134 pages thick, but the author can describe it in a detailed and concise manner so that both studies, facts, and ideas so far have been listed in the outline of the theme from the author's book, namely renewal of educational thinking Paulo Freire. The authors have also revitalized this idea to be studied and applied to Indonesian education (Chapter 9). This is a breakthrough for the author to decide whether this thinking will be applicable in Indonesia. Through thinking from the author's point of view alone to discuss this, studies are also sourced from book sources, journals, and even surveys to get studies or writings that can be trusted and accounted for.

In every book, there must be something he likes or has advantages, including a book by Mi'raj, "The Renewal of Paulo Freire's Educational Thought"—describing the thoughts of an educational figure, Paulo Freire, who is very profound, so that readers can understand it in addition to adding insight and knowledge. the content of the context also integrates Freire's thinking into education in Indonesia so that it has a different perspective in assessing education in Indonesia using Freire's philosophy. Having reliable sources both from local and foreign sources, there are even survey results displayed so as to provide concrete and reliable evidence for readers. From the sentence structure, it is integrated and comprehensive so that readers can quickly understand it.

The context study is quite interesting and is still relevant in today's life, not only in Indonesia, It examines the thoughts of a significant educational figure. Education is essential for human life, but not a corrupt education that only cares for certain parties and ignores humanity. So there are lots of problems such as oppression and so on. Although discussing something that can be said to be epic, the suggestion from book reviews for book authors is to add statistical data or tables, because in the source there are survey results, it is better to put them in a table to make it easier to understand, not just a short narrative. For the Acknowledgment Section on page VII, try to have formal content because the context is social and educational. On this page, there are less formal words and some sentences from the author himself. However, the content is meaningful, and it is hoped that it will not stop at this book, but there will be a dialectic of other discussions about education. As for readers, the review suggests understanding in depth, not just reading, because if there are parts that are missed or poorly understood, it will lead to misinterpretations. Readers can also take knowledge and have a good impact on their lives.

\section{REFERENCE}

Kurniawan MD. Pembaharuan Pemikiran Pendidikan Paulo Freire. Pertama. Malang: Intrans Publishing; 2021. 134 p.

\section{AUTHOR:}

Mi'raj Dodi Kurniawan, born in Cianjur, West Java, March 30, 1981. Completed primary to secondary education in his hometown. Graduates of S1 History Education at the Institute of Teacher Training and Education / IKIP Bandung or what is now known as UPI, then S2 in the same study program and campus. The author is diligent in writing down ideas in various media, including Pikiran Rakyat, Tribun Jabar, Radar Sukabumi, Galamedia, and others. The author has also won a student writing competition in West Java. In addition, he also served as General Secretary of the UPI History Education Student Association. Now the author is the Chairman of the West Java Province Regional Archipelago Alliance. 